\title{
PENGUATAN PENDIDIKAN KARAKTER BERBASIS MASYARAKAT PADA SEKOLAH MENENGAH PERTAMA NEGERI (SMPN) DI KABUPATEN TULANG BAWANG PROVINSI LAMPUNG
}

\author{
${ }^{1}$ Yetri, ${ }^{2}$ Rijal Firdaos \\ ${ }^{1}$ yetri.hasan@ radenintan.ac.id ${ }^{2}$ rijalfirdaos@ 1 radenintan.ac.id \\ Universitas Islam Negeri Raden Intan Lampung
}

\begin{abstract}
This research aims to see the school's efforts in strengthening community-based character education, especially related to how to build participation and collaboration between schools and communities in the successful implementation of character education strengthening with school extracurricular activities. Research This is Qualitative research as this study uses a natural setting, with the aim of interpreting phenomena that occur and are carried out by means of involving several existing methods. In conducting data collection, this study uses $F G D$, interviews and observations. The next data is processed quantitatively from the results of the study. First; that the ability of schools to build collaboration and involvement of the community in KDP, still faces various obstacles and can be categorized as not optimal. Second; in general the community is enthusiastic about welcoming the KDP program, and has the willingness to actively participate in participating in the success of the KDP program. Third; schools have not yet discovered the design activities or design implementation that fits the needs of the school (interests, talents, abilities and creativity of the school and local wisdom in the school environment). And fourth; the design model for KDP implementation through extracurricular activities offered in this study is still a basic model, which can be adopted and modified by schools that adjust the school conditions, willingness and readiness of the community.
\end{abstract}

Keywords: Character and Community Education

\begin{abstract}
Abstrak
Penelitain Ini memiliki tujuan untuk melihat upaya sekolah dalam melakukan penguatan pendidikan karakter berbasis masyarakat, khususnya terkait dengan bagaimana membangun partisipasi dan kolaborasi antara sekolah dengan masyarakat dalam mensukseskan pelaksanaan penguatan pendidikan karakter dengan kegiatan ekstrakuikuler sekolah.Penelitian Ini merupakan penelitian Kualitatatif sebagai penelitian ini menggunakan latar alamiah, dengan tujuan menafsirkan fenomena yang terjadi dan dilakukan dengan cara melibatkan beberapa metode yang ada. Dalam melakukan pengumpulan data, penelitian ini menggunakan FGD, wawancara dan observasi.Selanjutnya data diolah secara kuantitatif Dari hasil penelitian.Pertama; bahwa kemampuan sekolah membagun kolaborasi dan perlibatan masyarakat dalam PPK, masih mengahadapi berbagai kendala dan dapat dikategorikan belum optimal.Kedua; pada umumnya masyarakat berantusias menyambut program PPK, dan memiliki kemauan untuk berpartisipasi aktif dalam ikut mensukseskan program PPK. Ketiga; sekolah selama ini belum menemukan desain kegiatan atau desain implementasi yang sesuai kebutuhan sekolah (minat, bakat, kemampuan dan kreatifitas sekolah serta kearifan lokal di lingkungan sekolah).Dan keempat; desain model implementasi PPK melalui kegiatan ekstrakurikuler yang ditawarkan dalam penelitian ini, masih merupakan model dasar, yang bisa diadopsi dan dimodifikasi oleh sekolah yang menyesuaikan kondisi sekolah, kesediaan dan kesiapan masyarakat.
\end{abstract}

Kata Kunci :Pendidikan Karakter dan Masyarakat 


\section{PENDAHULUAN}

Permasalahan terbesar bangsa Indonesia saat ini adalah adanya ancaman penurunan nilai karakter ditengah masyarakat, sebagai akibat dari terjadinya perubahan lingkungan global yang melanda hampir seluruh bangsa di dunia. Kegelisahan masyarakat terhadap perubahan tersebut, tentu menuntut perlunya berbagai strategi tepat guna untuk menyiapkan sumber daya manusia berkualitas dan tetap survive dalam menjaga jati dirinya dalam suatu bangsa. Dalam konteks ini, Indonesia telah menempatkan sektor pendidikan sebagai sektor yang sangat penting.

Berdasarkan fungsi pendidikan nasional di atas, jelas bahwa pendidikan di setiap jenjang, termasuk Sekolah Menengah Pertama Negeri (SMPN) Kabupaten Tulang Bawang yang dipilih oleh pemerintah pusat sebagai sekolah rujukan program Penguatan Pendidikan Karakter, harus diselenggarakan secara terstruktur dan kolaboratif guna mencapai tujuan tersebut. Hal itu berhubungan dengan pembentukan karakter peserta didik agar mampu bersaing, beretika, bermoral, sopan santun dan berinteraksi dengan masyarakat.

Upaya-upaya penguatan terhadap pendidikan karakter, juga sudah lama dilakukan pemerintah, diantaranya dengan melakukan Gerakan Nasional Pendidikan Karakter Bangsa Tahun 2010 yang kemudian dilajutkan dengan program Penguatan Pendidikan Karakter (PPK) pada tahun 2016. Hal ini sesuai dengan salah satu butir Nawacita melalui Gerakan Revolusi Mental yang di maklumatkan presiden Joko Widodo. Pendidikan karakter dapat dimulai sejak dini atau anak-anak, dengan caramenghafalkan Surat-surat pendek dalam al-quran dan lain sebagainya. Anak diajak mengenal ciptaan Alah berupa alam semesta yang berada disekitar kehidupan anak, pepohonan yang hijau, sawah terbentang luas, buah-buahan yang nikmat cita rasanya, semuanya anugerah Allah untuk manusia. Dan pada saatnya anak dapat mengenal dan memiliki jati diri di hadapan Allah dan di hadapan manusia dan makhluk ciptaan Allah lainnya.(Sada, 2015)

Di samping itu, Kementerian Pendidikan Nasional juga telah mengembangkan grand design pendidikan karakter di setiap jalur, jenjang, dan jenis satuan pendidikan.Grand design menjadi sumber rujukan konseptual dan operasional pengembangan, pelaksanaan, dan penilaian pendidikan karakter. Sebagai tindak lanjut kebijakan tersebut, pemerintah telah merumuskan lima nilai utama karakter yang saling 
berhubungan membentuk jejaring nilai serta perlu dikembangkan sebagai prioritas gerakan PPK. Kelima nilai utama karakter bangsa tersebut adalah ; (1) relegius, (2) Nasionalis, (3) mandiri, (4) Gotong royong, dan (5) integritas.

Secara faktual, sekolah masih menghadapi berbagai kendala dalam pendidikan karakter.Salah satunya terkait dengan kapasitas SDM sekolah, dalam membagun potensi, partisipasi serta kolaborasi dengan masyarakat guna mendukung penguatan pendidikan karakter melalui kegiatan ekstrakurikuler sekolah.Selama ini sekolah belum menunjukkan kemampuan yang optimal dalam mendesain pola partisipasi dan kolaborasi antara sekolah dengan masyarakat sebagai pendukung penguatan pendidikan karakter siswa.Sehingga yang terjadi selama ini, sekolah lebih berkutat pada optimalisasi pemberdayaan sumber-sumber yang tersedia di sekolah saja. Padahal di satu sisi, basis penguatan pendidikan karakter itu ada di dalam masyarakat

Memperhatikan hasil kajian di atas, kiranya masih dibutuhkan pemikiran mendalam tentang upaya sekolah dalam melakukan penguatan pendidikan karakter berbasis masyarakat, khususnya terkait dengan bagaimana membangun partisipasi dan kolaborasi antara sekolah dengan masyarakat dalam mensukseskan penguatan pendidikan karakter dengan kegiatan ekstrakurikuler sekolah.Oleh karena itu, penelitian tentang pengutana pendidikan karakter berbasis masyarakat ini perlu dilakukan.Istilah karakter sendiri, dapat diartikan sebagai tabiat, perangai, dan sifat-sifat seseorang.Karakter terbentuk melalui interaksi yang penuh muatan perasaan dan kedekatan dengan anak sehingga nilai-nilai moral dapat dicapai dan dihayati dan selanjutnya menjadi bagian dari sikap dirinya yang dilakukan dalam tindakan kehidupan.

Menurut Samami dan Hariyanto, karakter dimaknai sebagai nilai dasar yang membangun kepribadian seseorang, terbentuk baik karena pengaruh hereditas maupun lingkungan, yang membedakan dengan orang lain, serta diwujudkan dengan orang lain serta diwujudkan dalam sikap dan prilaku dalam kehidupan sehari-hari. Sebagai totalitas dari proses psikologis dan sosial-kultural, karakter dikelompokan dalam: Olah Hati (Spiritual and emotional development), Olah Pikir (intellectual development), Olah Raga dan Kinestetik (Physical and kinestetic development), dan Olah Rasa dan Karsa (Affective and Creativity development). (Muclas \& Hariyanto, 2011)

Dalam konteks pendidikan, Megawati menjelaskan pendidikan karakter adalah 
sebuah usaha untuk mendidik anak-anak agar dapat mengambil keputusan dengan bijak dan mempraktekannya dalam kehidupan sehari-hari, sehingga mereka dapat memberi konstribusi positip terhadap lingkungannya.Selanjutnya bahwa pendidikan karakter merupakan kunci susksesnya suatu bangsa.(Al Munawar, 2005)

Terkait dengan proses pembelajarannya, pendidikan karakter seharusnya tidak perlu menjadi suatu pelajaran sendiri, pendidikan karakter dapat diitegrasikan dalam pembelajaran dalam setiap mata pelajaran, melalui penanaman nilai-nilai budaya sekolah, atau dalam kegiatan ekstrakurikuler sekolah. Dengan demikian, pembelajaran nilai-nilai karakter tidak hanya pada berfokus pada tataran kognitif, tetapi lebih menyentuh pada internalisasi dan pengamalan nyata dalam kehidupan seharai-hari peserta didik.

Konsep dan desain penguatan pendidikan karakter muncul dan menjadi issu penting dalam dunia pendidikan saat ini, berangkat dari pandangan bahwa, perlu dilakukan penataan dan penempatan kembali karakter sebagai ruh atau dimensi terdalam pendidikan nasional berdampingan dengan intelektualitas yang tercermin dalam kompetensi.Dengan karakter yang kuat-tangguh beserta kompetensi yang tinggi, yang dihasilkan oleh pendidikan yang baik, pelbagai kebutuhan, tantangan, dan tuntutan baru dapat dipenuhi atau diatasi.Oleh karena itu, selain pengembangan intelektualitas, pengembangan karakter peserta didik sangatlah penting dalam sistem pendidikan nasional Indonesia.Dikatakan demikian karena pada dasarnya pendidikan bertujuan mengembangkan potensi-potensi intelektual dan karakter peserta didik.

Penguatan pendidikan karakter dapat dimaknai sebagai pengejawantahan Gerakan Revolusi Mental sekaligus bagian integral Nawacita.Gerakan PPK menempatkan pendidikan karakter sebagai dimensi terdalam atau inti pendidikan nasional sehingga pendidikan karakter menjadi poros pelaksanaan pendidikan dasar dan menengah.Lebih lanjut, Gerakan PPK perlu mengintegrasikan, memperdalam, memperluas, dan sekaligus menyelaraskan berbagai program dan kegiatan pendidikan karakter yang sudah dilaksanakan sampai sekarang. Dalam hubungan ini pengintegrasian dapat berupa pemaduan kegiatan yang ada didalam kelas, luar kelas, dan luar sekolah (masyarakat/komunitas); pemaduan kegiatan intrakurikuler, kokurikuler, dan ekstrakurikuler; pelibatan secara serempak warga sekolah, keluarga, dan masyarakat; perdalaman dan perluasan dapat berupa penambahan dan 
pengintensifan kegiatan-kegiatan yang berorientasi pada pengembangan karakter siswa, penambahan dan pemajanan kegiatan belajar siswa, dan pengaturan ulang waktu belajar siswa di sekolah atau luar sekolah; kemudian penyelerasan dapat berupa penyesuaian tugas pokok guru, Manajemen Berbasis Sekolah, dan fungsi Komite Sekolah dengan kebutuhan PPK.

Berangkat dari penjelasan di atas, maka upaya peningkatan pendidikan karakter menempati kedudukan fundamental dan strategis pada saat pemerintah mencanangkan revolusi karakter bangsa sebagaimana tertuang dalam Nawacita (Nawacita 8), menggelorakan Gerakan Nasional Revolusi Mental, dan menerbitkan RPJMN 2014/2019 berlandaskan Nawacita. Sebagai pengejawantahan Gerakan Nasional Revolusi Mental sekaligus bagian integral Nawacita, upaya penguatan pendidikan karakter menempatkan karakter sebagai dimensi terdalam atau sebagai inti pendidikan nasional.Lebih lanjut, upaya penguatan pendidikan karakter dalam paktiknya perlu adanya pengintegrasian, memperdalam, memperluas, dan sekaligus juga menyelaraskan berbagai program serta kegiatan pendidikan karakter yang sudah dilaksanakan hingga sekarang, agar tujuan dan fungsi pendidikan karakter iru sendiri dapat dicapai dengan baik.

Berdasarkan penelitian terdahulu, sudah ada penelitian yang meneliti mengenai pendidikan berbasis karakter yang terdapat sistem pendidikan khususnya di sekolah (Abdullah, Radiansyah, \& Akbar, 2015; Adibatin, 2016; Afifuddin, 2016; Fahmi, 2015; Irawan, 2013; Isnaini, 2016; Judiani, 2016; Mudlofir, 2013; Mukhibat, 2014; Siregar, 2017; Sumarni, Dardiri, \& Zuchdi, 2015). Serta telah dilakukan penelitian yang berbasis masyarakat(Adi \& Rahdriawan, 2017; Budiarti, Suwarto, \& Muflikhati, 2013; Pranoto \& Yusuf, 2016; Soares, Antara, \& Andhika, 2017; Sodiah, 2016). Namun belum adanya penelitian yang melakukan penguatan pendidikan karakter berbasis masyarakat, khususnya terkait dengan bagaimana membangun partisipasi dan kolaborasi antara sekolah dengan masyarakat dalam mensukseskan pelaksanaan penguatan pendidikan karakter dengan kegiatan ekstrakuikuler sekolah. Maka penelitian ini bertujuan untuk melihat upaya sekolah dalam melakukan penguatan pendidikan karakter berbasis masyarakat

\section{METODE PENELITIAN}


Dilihat dari jenis datanya, pendekatan dalam penelitian ini adalah pendekatan kualitatif. Penelitian kualitatif dimaksudkan untuk memahami fenomena tentang apa yang dialami oleh subjek penelitian secara holistik, dan dengan cara deskripsi dalam bentuk kata-kata dan bahasa, pada suatu konteks khusus yang alamiah dan dengan memanfaatkan berbagai metode ilmiah. (Lexy J, 2012)Penelitian kualitatif juga dapat dijelaskan sebagai penelitian yang menggunakan pedekatan alamiah, dengan tujuan menafsirkan fenomena yang terjadi dan dilakukan dengan cara melibatkan berbagai metode yang ada. Dalam konteks ini peneliti adalah sebagai instrumen kunci, dan teknik pengumpulan data dilakukan dengan cara triangulasi (gabungan), analisis data bersifat induktif kualitatif, dan hasil penelitian kualitatif lebih kepada makna dari pada generalisasi.

Alat pengumpul data menggunakan FGD, wawancara dan observasi.Analisis data secara kualitatif deskriptif, yakni dengan mendeskripsikan keadaan data/informasi yang sudah diperoleh melalui instrumen penelitian selanjutnya diolah sesuai fokus dan temanya. Langkah-langkah analisis datanya meliputi: (1) reduksi data, (2) penyajian data, dan (3) verifikasi dan penarikan kesimpulan.

\section{HASIL PENELITIAN DAN PEMBAHASAN}

Temuan pertama penelitian ini berhubugan dengan kemampuan sekolah membagun kolaborasi dan perlibatan masyarakat dalam PPK.Dalam konteks ini dijelaskan bahwa kedua sekolah sasaran penelitian, merupakan sekolah yang ditetapkan pemerintah sebagai sekolah rujukan PPK, sejak tahun 2017.Dan masing-masing sekolah telah mengikuti Bimtek PPK.Bimtek diikuti Kepala Sekolah dan salah satu Dewan Guru. Menurut penuturan guru yang mengikuti Bimtek, apa yang di peroleh dari kegiatan Bimtek sesungguhnya telah dilakukan di sekolah. Dengan kata lain, pendidikan karakter memang sudah berlangsung di sekolah baik melalui kegiatan ektsrakurikuler, budaya sekolah maupun kegiatan kurikuler yaitu melalui integrasi di dalam mata pelajaran. Namun selama ini kegiatan tersebut belum terselenggara secara baik, sistematis dan komprehensif.

Perencanaan kegiatan ekstrakurikuler kedua sekolah telah dilakukan. Beberapa unsur perencanaan kegiatan ekstrakurikuler dapat dilihat dari sejumlah kegiatan yang di bentuk sebelumnya, sedang dan setelah proses kegiatan ekatrakurikuler tersebut 
dilaksanakan. Di samping itu terdapat kejelasan hasil yang akan dicapai dalam kurun waktu tertentu. Namun demikian, dalam perencanaan program ekstrakurikuler tersebut belum terdeskripsikan secara spesifik upaya-upaya pembentukkan dan penguatan karakter peserta didik.Kegiatan ekstrakurikuler kedua sekolah sasaran, merupakan bagian integral dari Program Kerja Sekolah.Hal ini sesuai dengan yang disampaikan oleh Kepala Sekolah Banjar Margo, bahwa kegiatan ekstrakurikuler merupakan salah satu dari komponen dalam Program Kerja Sekolah, yang dalam kegiatan operasionalnya diserahkan pada Waka Kesiswaan.

Selanjutnya, dalam penelitian yang bertema penguatan pendidikan karakter berbasis masayarakat ini, peneliti telah mengidentifikasi beberapa kegiatan ekstrakurikuler yang ada di SMPN 2 Penwartama dan SMPN 2 Banjar Margo Tulang Bawang, yang telah ditunjuk oleh Kementerian Pendidikan dan Kebudayaan RI untuk melaksankan program Penguatan Pendidikan Karakter (PPK). Kegiatan ekatrakurikuler di kedua sekolah, hampir memiliki kesamaan dari segi jenisnya, masing-masing sekolah mengembangkan kegiatan ekstrakurikuler diantaranya berupa Pendidikan Kepramukaan, Rohis, Olahraga, Seni dan Hastakarya/Prakarya, Olahrag. Kecuali SMPN 2 Penawartama, selain yang sudah disebutkan di atas, SMPN 2 Penawartama juga sudah memiliki kegiatan ekstarkurikuler Drum Band.

Namun demikian, berdasarkan dokumen penyusunan program kegiatan ekstrakurikuler kedua sekolah, diketahui bahwa pengembangan kegiatan ekstrakurikuler yang dipilih sekolah belum sepenuhnya dilakukan berdasarkan analisis sumber daya yang dibutuhkan dalam penyelenggaraan kegiatan ekstrakurikuler, seperti analisis sumber daya yang berhubungan dengan ketenagaan, peserta didik, sarana dan pembiayaan yang tersedia, serta analisis perlibatan masyarakat sebagai sumber daya potensial dalam penguatan pendidikan karakter peserta didik.

Berdasarkan hasil Fokus Group Discussion (FGD) dan wawancara dengan masyarakat, terungkap bahwa sesungguhnya masyarakat begitu antusias menyambut program PPK, dan memiliki kemauan untuk berpartisipasi aktif dalam ikut mensukseskan program penguatan pendidikan karakter yang dicanagkan sekolah. Hanya saja komunikasi yang terjalin masih sangat kurang Masyarakat mengungkapkan belum pernah diundang sekolah untuk secara khusus membicarkan masalah ini.Mereka lebih banyak dilibatkan dengan urusan pembiayaan opersional sekolah, yang rutin diundang 
di awal peleksanaan semester atau awal tahun pembelajaran.

Dari hasil Fokus Group Discussion (FGD) ini juga diperoleh informasi bahwa pada dasarnya berbagai komponen masyarakat, baik secara individu (pengrajin rumah tangga, petani, pedagang makanan), melalui perkumpulan organisasi sosial yang ada (kelompok seni, pengajian, Risma, dan kelompok olahraga), bahkan dari instansi pemerintah daerah (Puskesmas dan Kepolisian), menyatakan kesediaan mereka bersama-sama sekolah untuk ikut menguatkan pendidikan karakter anak.

Lebih lanjut mereka menyatakan, mereka siap dengan keahlian dan profesi masing-masing melaksanakan program kegiatan dalam rangka mendampingi sekolah mendidik anak-anak sehingga menjadi lebih baik akhlak dan moralnya. Satu hal yang tidak kalah penting dari temuan penelitian ini, bahwa pada umumnya para guru juga memiliki kemauan dan ide-ide cerdas terkait dengan rancangan perlibatan masyarakat dalam program PPK.

Program PPK yang dicanangkan di sekolah sudah mulai disosialisasikan, namun masih terbatas pada warga sekolah, dan belum secara intensif memanfaatkan forum KKG , MGMP dan Komite sekolah sebagai tempat strategis untuk mensosialisasikan program PPK tersebut, baik kepada internal sekolah. maupun warga masyarakat. Selanjutnya, umumnya pada kedua sekolah sasaran, pendidikan nilai-nilai karakter yang dilaksanakan selama ini, sudah teritegrasi dalam kegiatan ekstrakurikuler yang dikembangkan sekolah, seperti dalam kegiatan olah raga, seni budaya, pramuka, dan keagamaan, namun kemampuan guru masih belum optimal dalam penguatan pendidikan karakter tersebut, masih terdapat guru justru terperangkan dalam mengedepankan substansi materi atau konten kegiatan ektrakurikuler dibandingkan dengan nilai-nilai karakter yang harus dibentuk melalui kegiatan tersebut.

Terkait dengan ketersediaan sarpras, pada umumnya sekolah masih menghadapi kendala dalam program PPK, khususnya Aula sekolah/GSG, yang sangat diperlukan untuk melaksnakan PPK secara bersama untuk setiap jenjang kelas ( kelas besar). Untuk fasilitas aula ini kedua sekolah sasaran belum ada yang memiliki aula sekolah.Demikian juga dengan fasilitas lainnya yang bersinggungan langsung dengan kegiatan ekstrakurikuler sekolah, seperti sarana untuk kegiatan seni, dan yang lainnya.

Temuan kedua penelitian ini adalah terkait dengan model implementasi Penguatan Pendidikan Karakter Berbasis Masyarakat di sekolah.Dalam konteks ini 
dijelaskan bahwa pendidikan karakter sesungguhnya sudah dilaksanakan di kedua sekolah sasaran.Namun, masih perlu dilakukan berbagai terobosan dan inovasi supaya pendidikan karakter bisa dilaksanakan secara konsisten oleh sekolah serta memberikan dampak nyata perbaikan moral dan akhlak peserta didik.Penerapan penguatan pendidikan karakter membutuhkan komitmen, dan kebersamaan, serta dukungan dari semua pihak. Hal ini dikarenakan program Penguatan Pendidikan Karakter (PPK) membutuhkan waktu yang dimulai dari pengenalan, pembiasaan, hingga pencapaian tujuanya. Oleh karena itu, dibutuhkan pendekatan berfikir yang terstruktur dan komprehensif, berupa sebuah model implementasi sebagai panduan atau acuan dalam pelaksanaannya.

Fakta di lapangan juga menunjukkan, bahwa pada dua sekolah sasaran penelitian, belum ada satu sekolahpun menyiapkan desain model implementasi program PPK tersebut.Pada hal disatu sisi, model implementasi dapat membantu sekolah menyesuaikan program dengan kapasitas dan kemampuan sekolah.Dan dengan model implementasi PPK, dapat mendorong peserta didik menumbuhkembangkan karakter positifnya melalui berbagai kegiatan, khususnya kegiatan ekstarkurikuler sekolah.

Dengan model implementasi ini juga, dapat diatur tema-tema PPK setiap dilakukan kegiatan bersama masyarakat, penyesuaian dengan minat serta bakat siswa yang dilakukan dibawah bimbingan guru/pelatih dan melibatkan orang tua sertamasyarakat. Hasil penelitian yang dianalisis berdasarkan jenis-jenis kegiatan ekstrakurikuler yang diprogramkan di sekolah, serta peran serta masyarakat yang bisa dikembangkan, maka melalui penelitian ini peneliti mencoba mendesian model implementasi program PPK dengan mengadopsi dan mengadaptasi pada model yang selama ini telah dikenalkan oleh Kemendikbud (2016), yaitu dapat dilihat pada gambar 4.1 berikut ini : 


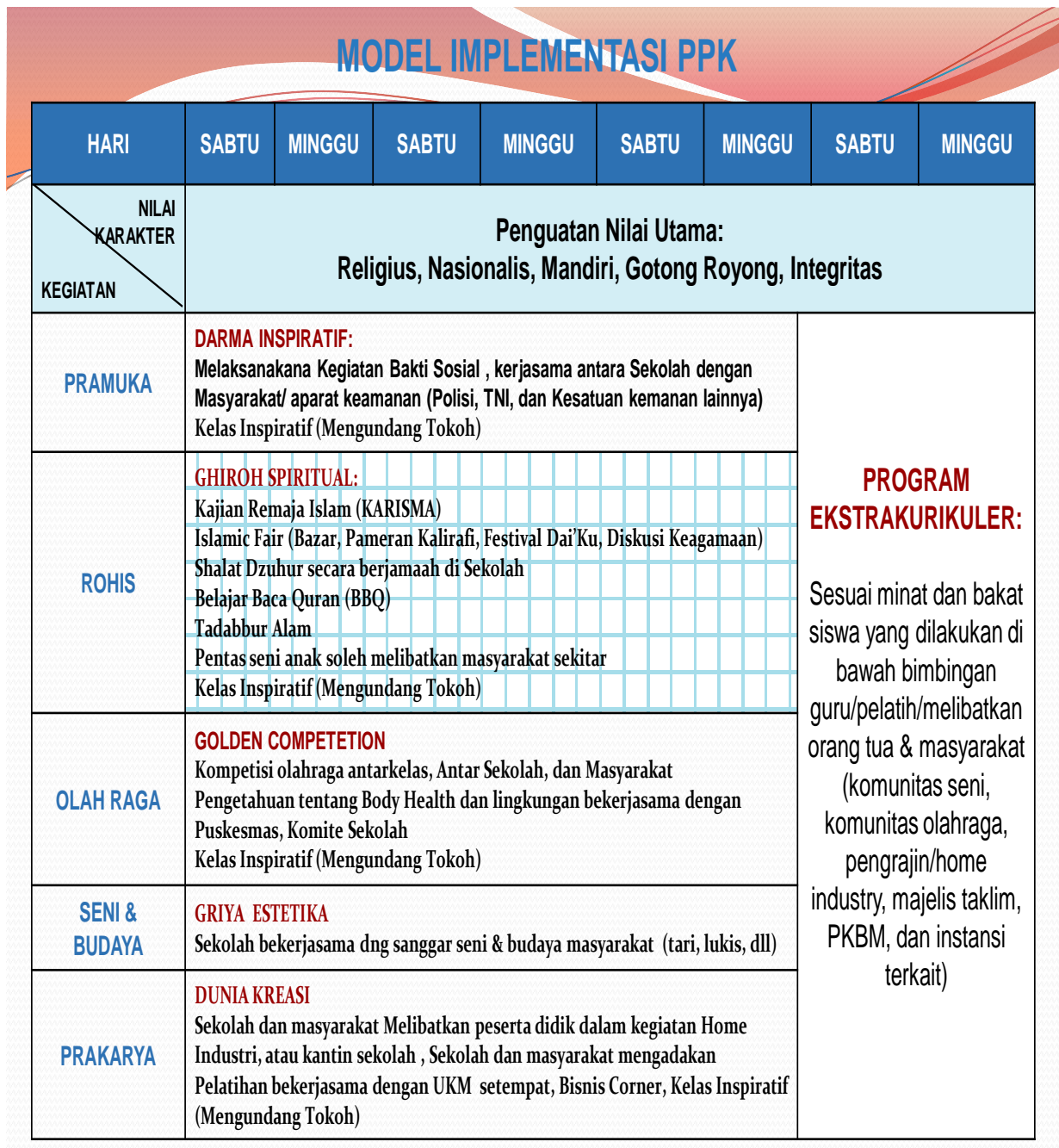

* Durasi waktu tidak mengikat dan disesuaikan dengan kondisi sekolah, kesediaan dan kesiapan masyarakat

** Nilai-nilai karakter mengcover seluruh nilai utama, disesuaikan, kreativitas sekolah, dan kearifan lokal

\section{KESIMPULAN DAN SARAN}

Dari hasil penelitian dan pembahasan yang telah dipaparkan pada bab IV di atas, dapat disimpulkan, pertama; bahwa kemampuan sekolah membagun kolaborasi dan perlibatan masyarakat dalam PPK, masih mengahadapi berbagai kendala dan dapat dikategorikan belum optimal. Dari hasil FGD dan wawancara dengan pihak sekolah dan masyarakat, terungkap bahwa hal ini terjadi disebabkan oleh pola komunikasi yang selama ini belum terjalin secara efektif.Kedua; pada umumnya masyarakat begitu antusias menyambut program PPK, dan memiliki kemauan untuk berpartisipasi secara aktif dalam ikut mensukseskan program PPK. Demikian juga dengan guru, pada umumnya para guru juga memiliki kemauan dan ide-ide cerdas terkait dengan rancangan perlibatan masyarakat dalam program PPK. Ketiga; sekolah selama ini 
belum menemukan desain kegiatan atau desain implementasi yang sesuai kebutuhan sekolah (minat, bakat, kemampuan dan kreatifitas sekolah serta kearifan lokal di lingkungan sekolah).Dan keempat; desain model implementasi PPK melalui kegiatan ekstrakurikuler yang ditawarkan dalam penelitian ini, masih merupakan model dasar, yang bisa diadopsi dan dimodifikasi oleh sekolah disesuaikan dengan kondisi sekolah, kesediaan dan kesiapan masyarakat.

Adapun rekomendasi yang dapat diperoleh dari hasil penelitian ini adalah: Pertama; perlu revitalisasi peran Kepala Sekolah sebagai manager dan Guru sebagai inspirator PPK. Kedua, perlu revitalisasi peran Komite Sekolah sebagai badan gotong royong serta partisipasi masyarakat dalam program PPK. Ketiga, perlunya sekolah memiliki model implementasi kolaborasi penguatan pendidikan karakter antara sekolah dengan masyarakat, Pemda, lembaga penggiat pendidikan dan sumber-sumber belajar lainnya, dibawah koordinasi sekolah.Dan keempat, sekolah perlu menyiapkan prasarana dan sarana pembelajaran kesenian, olahraga, rohis, dan sebagainya, dimulai dari pembentukan jejaring kolaborasi perlibatan publik. 


\section{DAFTAR PUSTAKA}

Abdullah, B., Radiansyah, \& Akbar, A. (2015). Pendidikan Karakter Di Madrasah Aliyah Negeri ( MAN ) 2 Banjarmasin. Inferensia, Jurnal Penelitian Sosial Keagamaan, 9(2), 537-560.

Adi, I. K., \& Rahdriawan, M. (2017). Kajian Partisipasi Masyarakat Dalam Pengelolaan Sanitasi Berbasis Masyarakat di Kelurahan Mangunharjo Semarang. Jurnal Pengembangan Kota, 4(2), 151-159.

Adibatin, A. (2016). Pendidikan Karakter Bangsa Berbasis Strategi Pembelajaran Pakem Melalui Permainan Cincin Di Jempol Tangan (Karya Inovasi Pembelajaran Sekolah Dasar). Scholaria, 6(1), 1-18.

Afifuddin. (2016). Pendidikan Karakter Berbasis Al-Qur'an: Penerapan Pola Sistematika Nuzulnya Wahyu (Snw) Di Pondok Pesantren Hidayatullah Panyula Kabupaten Bone. Lentera Pendidikan, 19(1), 30-41.

Al Munawar, S. A. H. (2005). Aktualisasi Nilai-Nilai Qur'ani Dalam Sistem Pendidikan Islam (II). Ciputat: Ciputat Press.

Budiarti, T., Suwarto, \& Muflikhati, I. (2013). Pengembangan Agrowisata Berbasis Masyarakat pada Usaha Tani Terpadu Guna Meningkatkan Kesejahteraan Petani dan Keberlanjutan Sistem Pertanian. Jurnal Ilmu Pertanian Indonesia, 18(3), 200207.

Fahmi, M. R. (2015). Penguatan Pendidikan Nilai di Bidang FIQH; Studi Pemikiran Falak KH Abdul Rani Mahmud. At-Turats, 9(2), 57-66.

Irawan, I. (2013). Pengaruh Pendidikan Karakter Mahasiswa Terhadap Ketaatan Hukum (Studi Kasus Di Kampus Universitas Bina Nusantara). Humaniora, 4(2), 11051115.

Isnaini, R. L. (2016). Penguatan Pendidikan Karakter Siswa Melalui Manajemen Bimbingan dan Konseling Islam. Manageria: Jurnal Manajemen Pendidikan Islam, 1(1), 35-52.

Judiani, S. (2016). Implementasi Pendidikan Karakter di Sekolah Dasar Melalui Peguatan Pelaksanaan Kurikulum. Jurnal Pendidikan Dan Kebudayaan, 16(9), 280-289.

Lexy J, M. (2012). Metodologi Penelitian Kualitatif. Bandung: PT Remaja Rosdakarya.

Muclas, S., \& Hariyanto. (2011). Konsep dan Model Pendidikan Karakter. Bandung: PT Remaja Rosdakarya.

Mudlofir, A. (2013). Pendidikan Karakter: Konsep dan Aktualisasinya dalam Sistem Pendidikan Islam. Nadwa, 7(2), 230-363.

Mukhibat. (2014). Reinventing nilai-nilai Islam, Budaya dan Pancasila dalam Pengembangan Pendidikan Karakter. Jurnal Pendidikan Islam, 1(2), 247-265. 
Pranoto, A. R., \& Yusuf, D. (2016). Program CSR Berbasis Pemberdayaan Masyarakat Menuju Kemandirian Ekonomi Pasca Tambang di Desa Sarijaya. JSP : Jurnal Ilmu Sosial Dan Politik, 18(1), 39-50.

Sada, H. J. (2015). Konsep Pembentukan Kepribadian Anak Dalam Perspektif AlQur'an (Surat Luqman Ayat 12-19). Al-Tadzkiyyah: Jurnal Pendidikan Islam, 6(2), 253-272.

Siregar, L. Y. S. (2017). Full Day School Sebagai Penguatan Pendidikan Karakter ( Perspektif Psikologi Pendidikan Islam ). Fikrotuna, 5(2), 307-319.

Soares, E. M., Antara, I. M., \& Andhika, I. M. (2017). Strategi Pengelolaan Kawasan Lindung Manucoco Berbasis Masyarakat di Kota Administratif Atauro, Dili Tior Leste. Ecotrophic: Journal of Enviromental Science, 11(1), 15-22.

Sodiah. (2016). Manajemen Lembaga Pendidikan Islam Berbasis Masyarakat Dan Sekolah. Sosial Budaya, 13(1), 89-100.

Sumarni, S., Dardiri, A., \& Zuchdi, D. (2015). Pengembangan Model Pendidikan Karakter Berbasis Penguatan Modal Sosial Bagi Mahasiswa UIN Sunan Kalijaga. Jurnal Pembangunan Pendidikan: Fondasi Dan Aplikasi, 3(1), 44-57. 